\title{
SIMULTANEOUS DETERMINATION OF TIGECYCLINE AND ITS POTENTIAL IMPURITIES BY A STABILITY-INDICATING RP-HPLC-UV DETECTION TECHNIQUE
}

\author{
V. N. V. KISHORE ${ }^{1}$, G. V. RAMANA ${ }^{2}$ \\ ${ }^{1}$ Department of Chemistry, AG and SGS College, Vuyyuru 521165, India, ${ }^{2}$ Department of Chemistry, Andhra Loyola College, Vijayawada \\ 520008, A. P., India \\ Email: nagavelkiss@gmail.com
}

Received: 27 Feb 2021, Revised and Accepted: 18 Oct 2021

\begin{abstract}
Objective: Stability representing the RP-HPLC method was established for synchronized quantification of Tigecycline and its impurities. This method was confirmed for its applicability to both tablet dosage and bulk drug forms.
\end{abstract}

Methods: Intended for an isocratic elution, a mobile phase containing methanol: $10 \mathrm{mmol}$ Triethylamine Buffer mixture (75:25 v/v, pH 6.1) was used at $1 \mathrm{ml} / \mathrm{min}$ flow rate and Agilent ZORBAX Eclipse XDB $C_{18}(250 \mathrm{~mm} \times 4.6 \mathrm{~mm}, 5 \mu \mathrm{m})$ column.

Results: At $231 \mathrm{~nm}$ as wavelength, high-pitched peaks of Tigecycline (Tig) and its impurities (1and2) were detected at $6.55,8.73$ and 4.87 min correspondingly. The linearity of tigecycline and its impurities (impurity-1 and 2 and) were estimated with ranging from $75-450 \mu \mathrm{g} / \mathrm{ml}$ for Tigecycline and 1-6 $\mu \mathrm{g} / \mathrm{ml}$ for both impurity 1 and 2 . The corresponding recognition limits (LOD and LOQ) of the tigecycline and its impurities were originated to be $(1.37,0.047$ and $0.071 \mu \mathrm{g} / \mathrm{ml})$ and $(4.15,0.143$ and $0.126 \mu \mathrm{g} / \mathrm{ml})$.

Conclusion: The technique was effectively stretched for stability signifying studies under different stress conditions. Justification of the method was done as per the current ICH guidelines.

Keywords: Tigecycline, Impurities, Forced degradation, HPLC analysis, Method justification

(C) 2022 The Authors. Published by Innovare Academic Sciences Pvt Ltd. This is an open-access article under the CC BY license (https://creativecommons.org/licenses/by/4.0/) DOI: https://dx.doi.org/10.22159/ijap.2022v14i1.41243. Journal homepage: https://innovareacademics.in/journals/index.php/ijap

\section{INTRODUCTION}

Tigecycline (fig. 1a) is a glycylcyclines member that belongs to tetracycline derivative antibiotic medication used for the treatment of a number of bacterial infections and is potent against gram+ve and gram-ve organisms, including multi-drug resistance organisms [1]. Tigecycline is prescribed for the treatment of several bacterial infections including difficult skin/intra-abdominal contaminations and community-acquired bacterial pneumoni [2].

Tigecycline is the tetracycline derivative having $\mathrm{N}, \mathrm{N}$ dimethyglycylamido group in the 9-position of tetracycline ring and due to this structural modification, it having high minimal inhibitory concentrations against microbes than other tetracyclines [3]. It works by binding bacterial $30 \mathrm{~S}$ ribosomal subunit and blocks the interaction of aminoacyl-tRNA with the A site of the ribosome [4]. The side effects of Tigecycline are similar to that of the other tetracyclines. Vomiting and Nausea are the common side effects and swelling, pain, and irritation at the injection site are the less common side effects by the use of Tigecycline $[5,6]$. Every $5 \mathrm{ml}$ Tygacil container holds $50 \mathrm{mg}$ of tigecycline (web). This drug is used only in conditions where other different antibiotics are located not appropriate. Tigecycline and its impurities (fig. 1 b-c) 1 and 2 are degraded. Which are separated and characterized by NMR, HRMS and IR spectral investigation. In antimicrobial action Impurities, 1and2 shows good activity in the direction Gram-negative and Gram-positive. That's why Impurities 1 and 2 show good activity than Tigecycline [7].

The literature survey for the estimation of Tigecycline confirms that few HPLC [8-12] and one UV spectrophotometer [13] assay methods reported for the estimation of Tigecycline in pharmaceutical formulations. One bio-analytical method was reported for the estimation of Tigecycline in rabbit plasma [14]. Liquid chromatography-mass spectrometry (LCMS) analysis methods were reported for the estimation of Tigecycline in plasma and applied for pharmacokinetic study [15-18].

The review of the literature confirms that no analytical method was reported for the determination and quantification of Tigecycline and its related impurities. Hence the technique aimed to develop a simple and precise method for the separation and quantification of impurities 1 and 2 in bulk drug and formulations. The molecular structure of impurities 1 and 2 were given in fig. $1 \mathrm{~b}$ and $1 \mathrm{c}$, respectively. The established HPLC system was used for the evaluation of the drug with their impurities by in vitro method. Various abstractions were tried to used Methanol, Triethylamine $[11,19]$.<smiles>CN(C)c1cc(NC(=O)CNC(C)(C)C)c(O)c2c1C[C@H]1C[C@H]3[C@H](N(C)C)C(O)=C(C(N)=O)C(=O)[C@@]3(O)C(O)=C1C2=O</smiles>

1a. Tigecycline

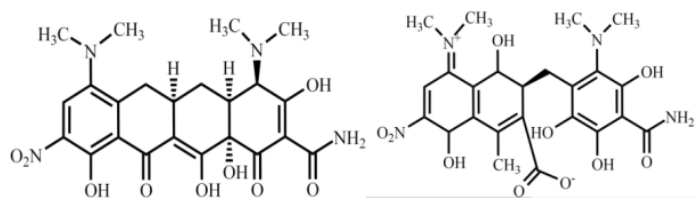

1b. Impurity 1

1c. Impurity 2

Fig. 1: Molecular structure of tigecycline and its impurities in the study

\section{MATERIALS AND METHODS}

Tigecycline standard drug with $98.73 \%$ purity and its Impurities studied were obtained from Lupin Ltd, Hyderabad. Methanol (HPLC Grade) and Acetonitrile (HPLC grade) were obtained as Merck chemicals, Mumbai. Ultra-Pure (Milli-Q ${ }^{\circledR}$ ) Water was used during the study. All the other substances used during the study are of analytical substance grade and were purchased from Merck chemicals, Mumbai. 


\section{General procedures}

Preparation of standard solutions: Standard stock solution of Tigecycline and its impurities were prepared by appropriately estimating about 10 $\mathrm{mg}(0.1 \mathrm{ml})$ of each drug $100 \mathrm{ml}$ volumetric flask separately. Then the drug was liquified in solvent and filter through a $0.45 \mu$ filter. Standard stock solution concentrations of $1000 \mu \mathrm{g} / \mathrm{ml}$ were obtained.

\section{Forced degradation and method validation studies}

According to the present rules [20], the last optimized conditions are validated. Diluted appropriately stress samples to prepare the closing concentration holding the planned method conditions (Tigecycline of $300 \mu \mathrm{g} / \mathrm{ml}$ ) and related with blank and standard chromatograms.

\section{Instrumentation}

To develop a High-Pressure Liquid Chromatographic method for the estimation of Tigecycline with impurities, isocratic PEAK HPLC instrument with Agilent ZORBAX Eclipse XDB C18(250 mm $\times 4.6$ $\mathrm{mm}, 5 \mu \mathrm{m}$ id) column, gradient pump (LC 20AT), programmable UVdetector (LC-7000) and the dyne type inject port (20 $\mu$ l capacity) and PEAK software for data analysis.

\section{RESULTS AND DISCUSSION}

\section{Method development}

On the basis of absorption maxima, experimental condition for tigecycline and its impurities the detector $\lambda$ max was set at $231 \mathrm{~nm}$ (fig. 2) for simultaneous determination of Tigecycline and its related impurities (impirity 1 and imp 2). $\lambda \max$ is lower in the present study (231 nm) compared to the studies carried out by other researchers like De Silva et al. [8] Suneetha et al. [9] Hua XI et al. [11] Mohan et al. 2017 [12] and Zorpas et al. [14] where $\lambda$ max was in the range of 247 to $270 \mathrm{~nm}$.

The iso-absorption wavelength observed for Tigecycline and its impurities 1 and 2 was considered as the optimum wavelength for the simultaneous detection of standard and both the impurities studied. The initial method development trials and the results observed in the studied conditions were summarized in table 1 and fig. 3 (a-d). The systematic trails of method development for the separation of Tigecycline and its impurities with acceptable system suitability were achieved using stationary phase is Agilent ZORBAX Eclipse XDB C18 (250 mm $\times 4.6 \mathrm{~mm}, 5 \mu \mathrm{m})$ column, Methanol and 10 mmol Triethylamine Buffer at $\mathrm{pH} 6.1$ in the ratio of 75:25 (v/v) as mobile phase at a flow rate of $1.0 \mathrm{ml} / \mathrm{min}$, UV detection was supported at a wavelength of $231 \mathrm{~nm}$ and the analysis was completed with a run time of $15 \mathrm{~min}$. In these conditions, acceptable system suitability was observed for both impurities and Tigecycline (fig. 4). In these conditions, retention times of Tigecycline and its impurities are $6.55,8.73$ and $4.87 \mathrm{~min}$ through a tailing factor of $1.18,0.95$ and 1.07 and the number of theoretical plates were found 4148,3370 and 5935, which indicates the column's fruit full output the \% RSD for six duplicate injections was around $0.138,0.367$ and 0.515 and the proposed method recommends that it is very precise. Hence these methods were validated through ICH Q2 (R1) [20] guidelines. These optimized chromatographic conditions are observed in table 2 . In the present study, eco-friendly methanol is used a solvent in the mobile phase, whereas acetonitrile was a solvent in other studies [8,9,11, 12 and 14].

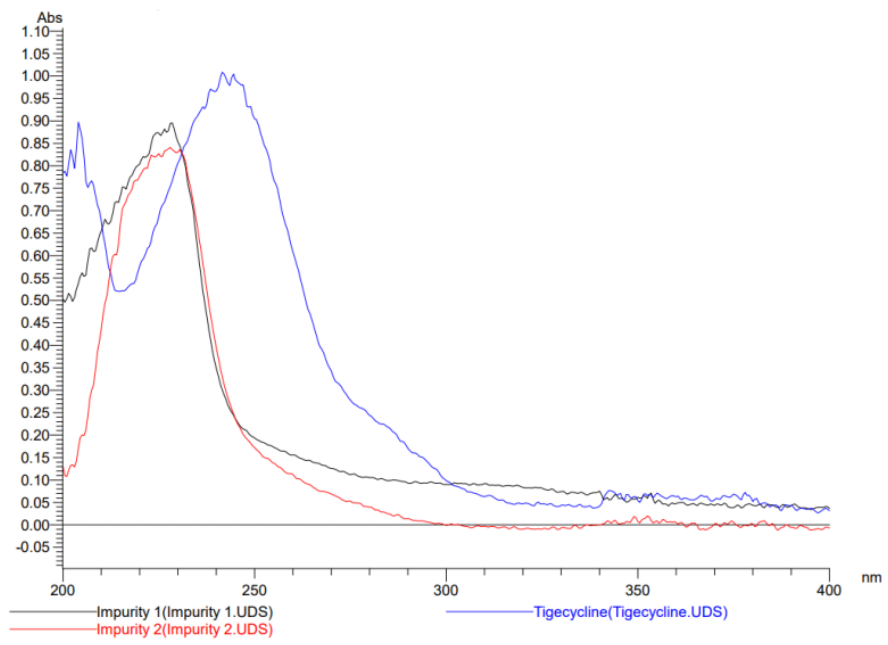

Fig. 2: UV-Visible spectrum of tigecycline and impurities (1 and 2)

Table 1: Optimization of method conditions for the separation of Tigecycline and its impurities

\begin{tabular}{|c|c|c|c|}
\hline S. No. & Condition studied & Result & Conclusion \\
\hline $\mathrm{a}$ & $\begin{array}{l}\text { MP: pH } 5.8 \text { phosphate buffer, methanol 80:20 (V/V); SP: } \\
\text { Zodiac c18 (100×4.6 mm; } 3.5 \mu \text { id) column; WL: } 231 \mathrm{~nm} \text {; } \\
\text { FR: } 1.0 \mathrm{ml} / \mathrm{min}\end{array}$ & $\begin{array}{l}\text { No separation was observed. two peaks were identified } \\
\text { and the peak corresponds to impurity } 2 \text { not detected } \\
\text { (fig. } 2 \text { a). }\end{array}$ & $\begin{array}{l}\text { Method } \\
\text { Rejected }\end{array}$ \\
\hline $\mathrm{b}$ & $\begin{array}{l}\text { MP: pH } 6.3 \text { acetate buffer: methanol } 50: 50(\mathrm{~V} / \mathrm{V}) \text {; SP: } \\
\text { ProntoSIL ODS C18 }(250 \times 4.6 \mathrm{~mm} ; 3.5 \mu \text { id }) \text { column; WL: } \\
231 \mathrm{~nm} \text {; FR: } 1.0 \mathrm{ml} / \mathrm{min}\end{array}$ & $\begin{array}{l}\text { Three peaks corresponds to three compounds studied } \\
\text { were identified but the separation was found to be very } \\
\text { less and broad peaks were observed (fig. } 2 \text { b). }\end{array}$ & $\begin{array}{l}\text { Method } \\
\text { Rejected }\end{array}$ \\
\hline c & $\begin{array}{l}\text { MP: pH } 5.9 \text { acetate buffer: methanol } 80: 20(\mathrm{~V} / \mathrm{V}) \text {; SP: } \\
\text { ProntoSIL ODS C18 }(250 \times 4.6 \mathrm{~mm} ; 5 \mu \mathrm{id}) \text {; WL: } 231 \mathrm{~nm} \text {; FR: } \\
1.0 \mathrm{ml} / \mathrm{min}\end{array}$ & $\begin{array}{l}\text { Three peaks corresponds to three compounds studied } \\
\text { were identified but the separation was found to be poor } \\
\text { compared with the previous trail and broad peaks were } \\
\text { observed (fig. } 2 \text { c). }\end{array}$ & $\begin{array}{l}\text { Method } \\
\text { Rejected }\end{array}$ \\
\hline $\mathrm{d}$ & $\begin{array}{l}\text { MP: Methanol and } 10 \mathrm{mmol} \text { Triethylamine Buffer at } \mathrm{pH} 6.1 \\
\text { in the ratio of } 80: 20(\mathrm{~V} / \mathrm{V}) \text {; SP: Phenomenex Luna C18 } \\
(250 \times 4.6 \mathrm{~mm} \text {; } 5 \mu \mathrm{id}) \text {; WL: } 231 \mathrm{~nm} \text {; FR: } 1.0 \mathrm{ml} / \mathrm{min}\end{array}$ & $\begin{array}{l}\text { Well resolved peaks corresponds to Tigecycline and its } \\
\text { impurities } 1 \text { and } 2 \text { were observed, but the base line was } \\
\text { fluctuating and tail factors were found to be high and the } \\
\text { poor peak response was observed (fig. } 2 \text { d). }\end{array}$ & $\begin{array}{l}\text { Method } \\
\text { Rejected }\end{array}$ \\
\hline e & $\begin{array}{l}\text { MP: Methanol and } 10 \mathrm{mmol} \text { Triethylamine Buffer at pH } 6.1 \\
\text { in the ratio of } 75: 25(\mathrm{~V} / \mathrm{V}) \text {; SP: Agilent ZORBAX Eclipse XDB } \\
\text { C18 }(250 \mathrm{~mm} \times 4.6 \mathrm{~mm}, 5 \mu \mathrm{m}) \text { column; WL: } 231 \mathrm{~nm} \text {; FR: } 1.0 \\
\mathrm{ml} / \mathrm{min}\end{array}$ & $\begin{array}{l}\text { Well resolved, retained peaks were observed with } \\
\text { acceptable system suitability and high peak responses } \\
\text { were observed (fig. 3). }\end{array}$ & $\begin{array}{l}\text { Method } \\
\text { Accepted }\end{array}$ \\
\hline
\end{tabular}




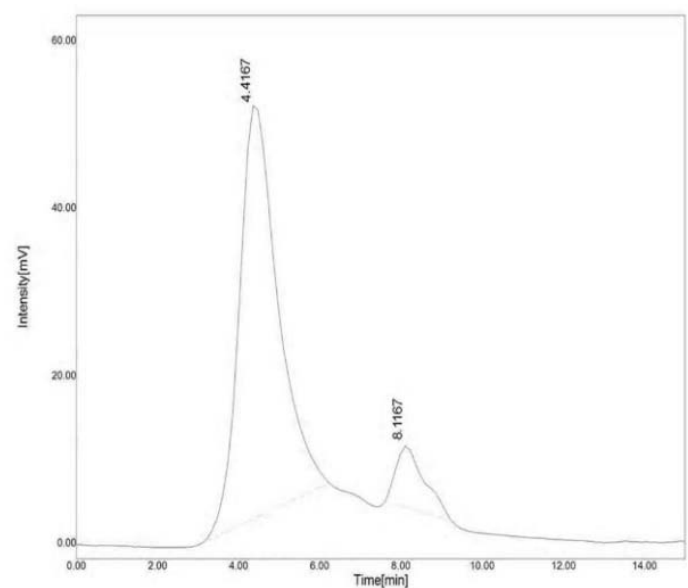

a)

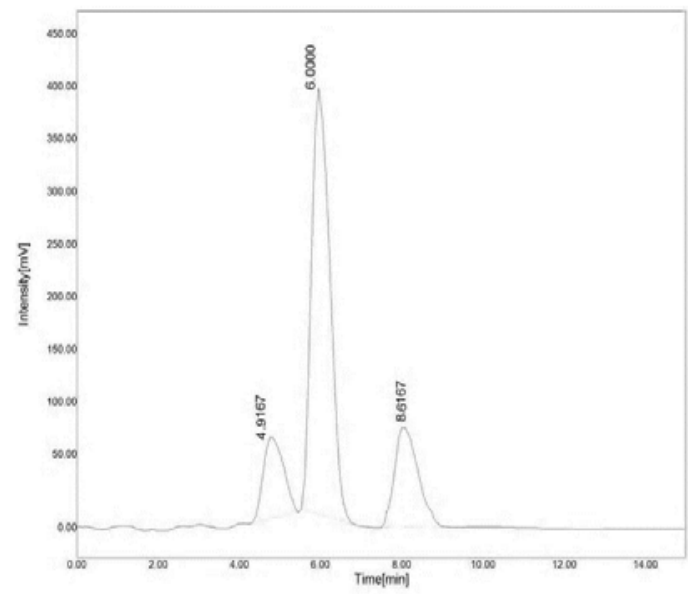

c)

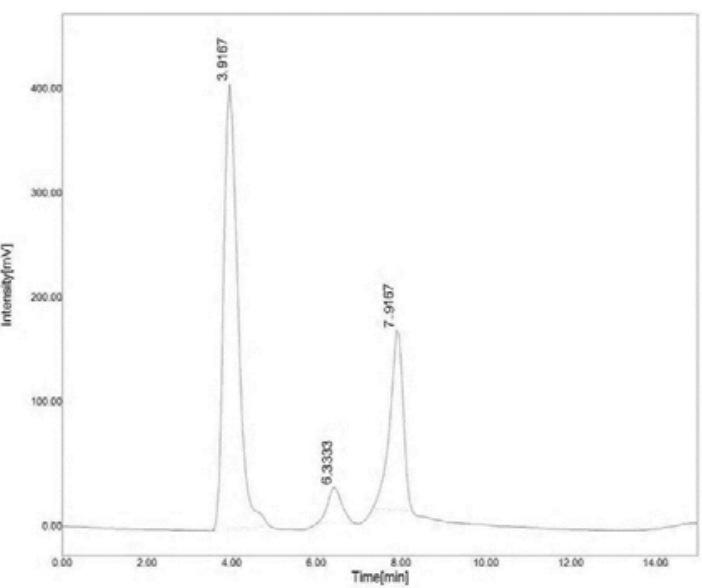

b)

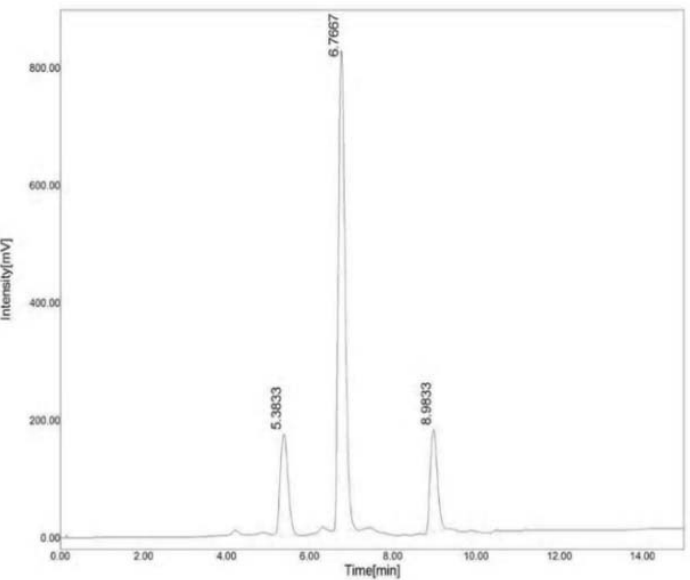

d)

Fig. 3 (a-d): Method optimization trails

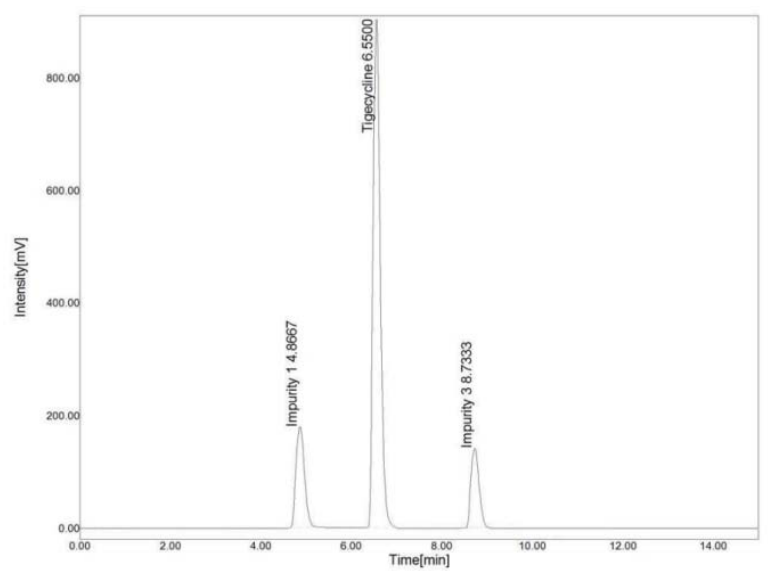

Fig. 4: Optimized chromatogram of tigecycline, impurity 1 and 2

Table 2: Optimized chromatographic conditions

\begin{tabular}{lll}
\hline S. No. & Parameter & Optimized condition \\
\hline 1 & Column & Agilent ZORBAX Eclipse XDB $\mathrm{C}_{18}(250 \mathrm{~mm} \times 4.6 \mathrm{~mm}, 5 \mu \mathrm{m}) \mathrm{column}$ \\
2 & Mobile Phase & Methanol: $10 \mathrm{mmol}$ Triethylamine Buffer $(75: 25 \mathrm{v} / \mathrm{v})$ \\
3 & Mobile phase $\mathrm{pH}$ & 6.1 \\
4 & Mobile phase flow rate $(\mathrm{ml} / \mathrm{min})$ & 1.0 \\
5 & Elution & Isocratic \\
6 & Wavelength $(\mathrm{nm})$ & 231 \\
7 & Sample volume & $20 \mu \mathrm{l}$ \\
\hline
\end{tabular}




\section{Stability indicating studies}

To determine the stability representing specificity and power of the planned method forced degradation conditions were studied. (fig. 6 (a-e)) Completely degradation mixtures under pressure situations were fine disconnected from each other as well as typical indicating of non-interference after somewhat degradation product. It gives information about the applicability of the establish method even for both unknown and known products. Understanding of the TIG in the direction of the acidic (10.15) and photolytic (7.96) situations is recognized from the high $\%$ of degradation (table 4).

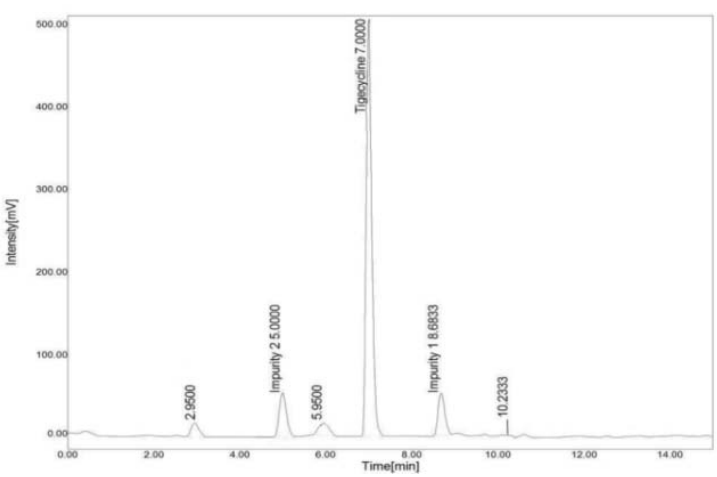

(a)

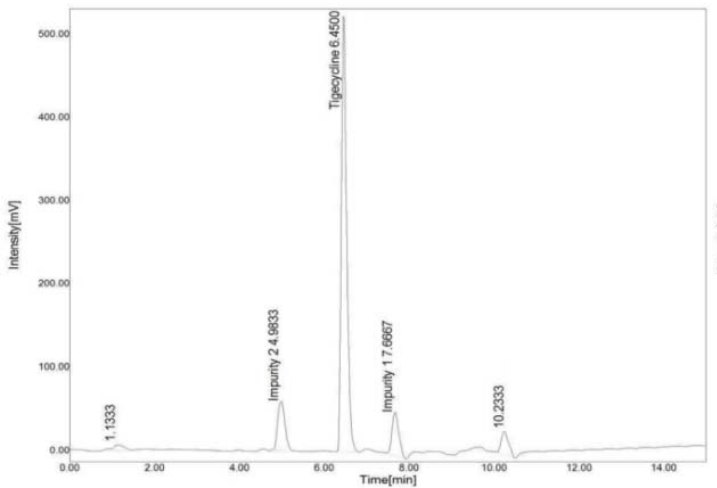

(c)

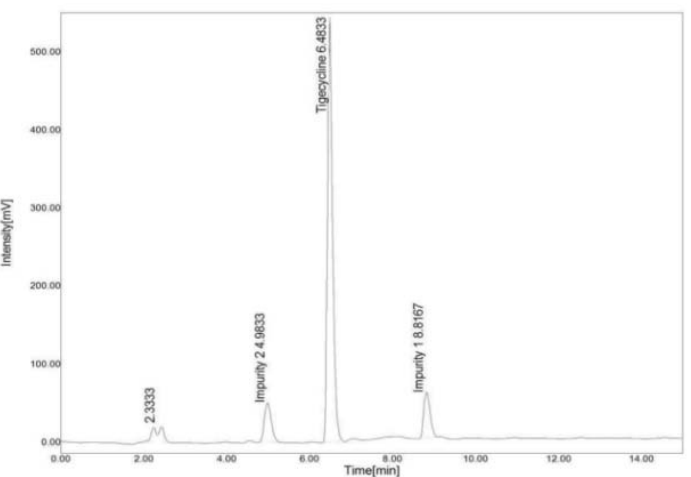

(b)

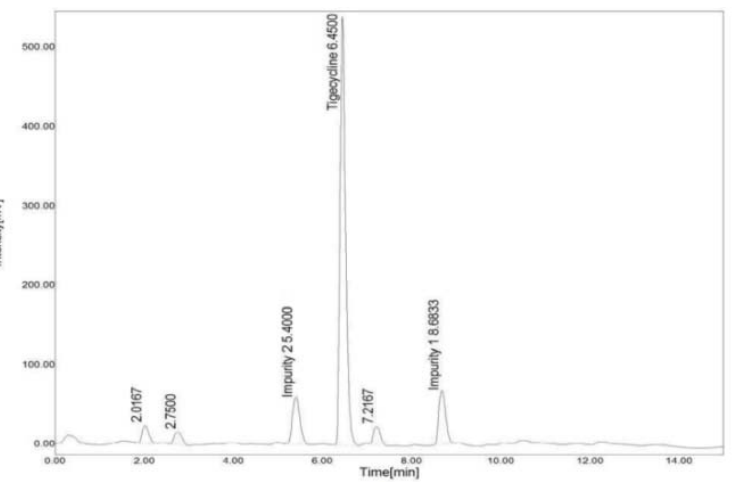

(d)

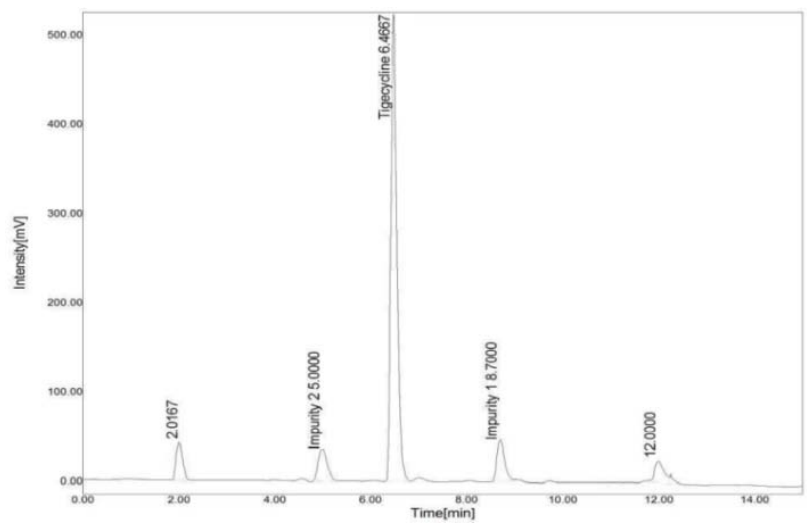

(e)

Fig. 5: Chromatograms of stability indicating studies under stress conditions a) Acidic, b) Alkali, c) Peroxide, d) Thermal and e) UV condition

Table 3: Results of forced degradation studies

\begin{tabular}{|c|c|c|c|}
\hline Parameter & Stress conditions & $\begin{array}{l}\text { Amount of degraded } \\
\text { sample }(\mathrm{A})(\mu \mathrm{g} / \mathrm{ml})\end{array}$ & $\begin{array}{l}\text { \% Degradation w. r. t. } \\
\text { control sample*(B) }\end{array}$ \\
\hline Control sample (No Degradation) & No Exposure & 305.71 & NA \\
\hline Acid degradation & $1 \mathrm{ml}$ of $0.5 \mathrm{~N} \mathrm{HCl}$ for $12 \mathrm{~h}$ at room temperature & 274.67 & 10.15 \\
\hline Base degradation & $1 \mathrm{ml}$ of $0.5 \mathrm{~N} \mathrm{NaOH}$ for $12 \mathrm{~h}$ at room temperature & 290.96 & 3.67 \\
\hline Oxidation & $2 \mathrm{ml}$ of $10 \% \mathrm{H}_{2} \mathrm{O}_{2}$ for $1 \mathrm{~h}$ at room temperature & 286.04 & 5.30 \\
\hline Thermal degradation & $70{ }^{\circ} \mathrm{C}$ for $48 \mathrm{~h}$ & 292.73 & 3.08 \\
\hline Photolytic degradation (UV) & 200-Watt hours/square meter & 277.99 & 7.96 \\
\hline
\end{tabular}

${ }^{*} \mathrm{~B}=(305.71-\mathrm{A}) / 305.71 * 100$ 


\section{Method validation}

Confirmed the above-optimized method for the corresponding quantification of tigecycline and its impurities as per the existing guidelines [20-25].

\section{System suitability and specificity}

Detected system suitability parameters and tabulated parameters were satisfactory and reported theoretical plate count values, tail factor and resolution values are tabulated in (table 3). Retention time in the present study is comparable to the studies of De Silva et al. [8] and Suneetha et al. [9] but less than Mohan et al. 2017 [12].

\section{Specificity}

In this way and standard, sample and placebo solutions were investigated separately to study the interference. Fig. 5 expressions the dynamic elements were well separated from blank and their excipients. There is no interference of placebo with the major peak. So these technique is specific.

Table 4: System suitability conditions

\begin{tabular}{|c|c|c|c|}
\hline \multirow[t]{2}{*}{ Parameter } & \multicolumn{3}{|c|}{ Results observed } \\
\hline & Tigecycline & Imp-1 & Imp-2 \\
\hline Api Concentration $(\mu \mathrm{g} / \mathrm{ml})$ & 300 & 4 & 4 \\
\hline Retention time (min) & 6.55 & 8.73 & 4.87 \\
\hline Peak Area & 985512 & 64034 & 59731 \\
\hline Resolution & 4.99 & ----- & 6.32 \\
\hline Theoretical plates & 4148 & 3370 & 5935 \\
\hline Tailing factor & 1.18 & 0.95 & 1.07 \\
\hline
\end{tabular}

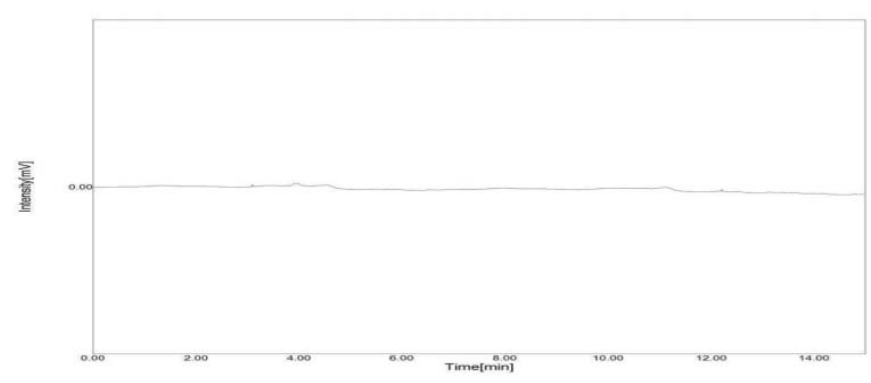

Fig. 6: Chromatogram of blank

\section{Linearity}

The linearity of tigecycline and its impurities (imp-1and 2 and) were estimated with ranging from 75-450 $\mu \mathrm{g} / \mathrm{ml}$ for Tigecycline and $1-6 \mu \mathrm{g} / \mathrm{ml}$ for both impurity 2 and 1 . The $\mathrm{R}^{2}$ value is greater than 0.999 (fig. 7) for both tigecycline and its impurities. Which gives information about the linearity of the method. These data are shown in table 5 . Linearity range $(\mu \mathrm{g} / \mathrm{ml})$ is wider in the present study (75-450) compared to the reports of De Silva et al. (40-100) Suneetha et al. (80 to 120) Mohan et al. 2017 (0.05-0.13) Zorpas et al. (0.021-3.15) [8, 9, 12 and 14].
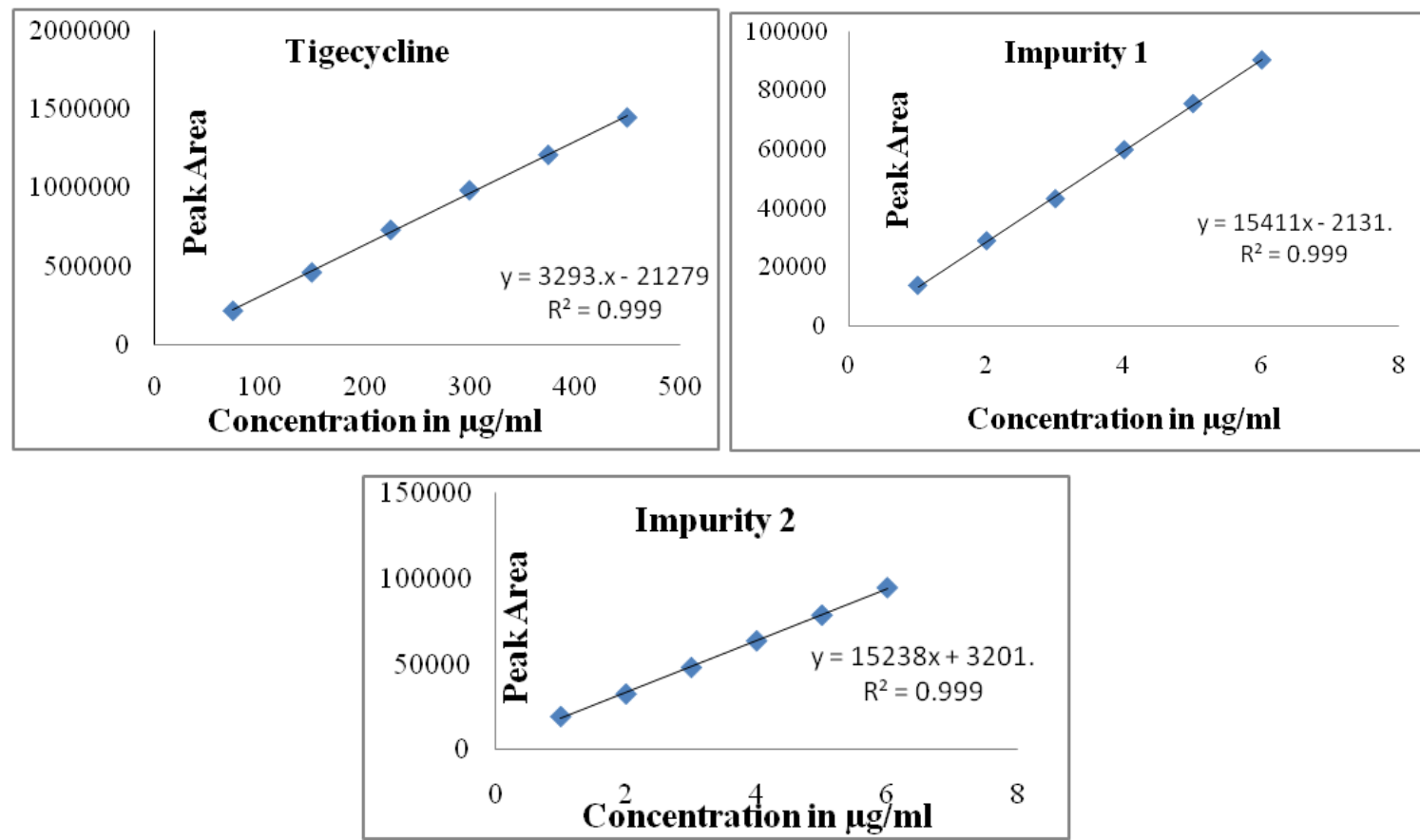

Fig. 7: Calibration graphs of tigecycline and impurities (1and2) 


\section{Method Precision (M. P.) and Intermediate Precision (I. P.)}

Six average trials (comprising a combination of $300 \mu \mathrm{g} \mathrm{ml}^{-1}$ of Tigecycline and $4 \mu \mathrm{g} \mathrm{ml}^{-1}$ of impurities) were inserted and the mean values of system suitability parameters were noted (table 6) and \% RSD values of M.P is $0.138,0.367$ and 0.515 and I.P is $0.122,0.582$ and 0.184 for Tigecycline and its impurities 1 and 2. Under the same conditions, \% Assay of Method precision (M.P) and intermediate precision (I.P) was found the range between (100.28-99.1, 100.43$100.08)$ for Tigecycline, $(100.81-100.12,101.43-98.76)$ for impurity 1 and $(100.10,98.49,100.16-99.63)$ for impurity 1 which shows to comparison the precision values (table 7). The precision of the method is established from the numerical results (\% RSD is less than 1 for both Tigecycline and impurities 1 and 2). Six standard replications of the combined to normal solution confirm that the analytical system is working correctly [26].

Table 5: Comparison of system suitability parameters in precision experiments

\begin{tabular}{|c|c|c|c|c|c|c|}
\hline \multirow{2}{*}{$\begin{array}{l}\text { System suitability } \\
\text { parameter }\end{array}$} & \multicolumn{3}{|l|}{ M. P. } & \multicolumn{3}{|l|}{ I. P. } \\
\hline & Tigecycline & IMP-1 & IMP-2 & Tigecycline & IMP-1 & IMP-2 \\
\hline USP resolution & 5.02 & 6.39 & ------ & 5.11 & 6.42 & - ----- \\
\hline USP tailing factor & 1.14 & 1.08 & 0.968 & 1.15 & 1.07 & 0.965 \\
\hline USP plate count & 4267 & 5872 & 3464 & 4225 & 5719 & 3467.5 \\
\hline R. T (min) & 6.50 & 8.70 & 5.03 & 6.53 & 8.90 & 5.12 \\
\hline Peak area & $986162 \pm$ & $59818 \pm$ & $63893 \pm 329.3$ & $988462 \pm$ & $59705 \pm$ & $64092 \pm$ \\
\hline mean $\pm S D$ & 1365.3 & 219.7 & & 1201.9 & 347.4 & 117.8 \\
\hline$\%$ RSD of area & 0.138 & 0.367 & 0.515 & 0.122 & 0.582 & 0.184 \\
\hline
\end{tabular}

Values are given in mean \pm SD; $n=6$

Table 6: Comparison of precision \% assay values

\begin{tabular}{|c|c|c|c|c|c|c|}
\hline \multirow[t]{3}{*}{ S. No. } & \multicolumn{6}{|l|}{ \% Assay } \\
\hline & \multicolumn{2}{|l|}{ Tigecycline } & \multicolumn{2}{|l|}{ Impurity 1} & \multicolumn{2}{|l|}{ Impurity 2} \\
\hline & M. P. & I. P. & M. P. & I. P. & M. P. & I. P. \\
\hline 1 & 100.06 & 100.08 & 100.21 & 99.90 & 99.71 & 100.16 \\
\hline 2 & 100.03 & 100.26 & 100.31 & 99.64 & 98.49 & 100.10 \\
\hline 3 & 100.19 & 100.15 & 100.43 & 98.76 & 99.36 & 99.80 \\
\hline 4 & 99.91 & 100.24 & 100.09 & 100.22 & 99.98 & 99.71 \\
\hline 5 & 99.92 & 100.43 & 100.81 & 101.43 & 100.10 & 99.85 \\
\hline 6 & 100.28 & 100.35 & 101.12 & 100.21 & 99.80 & 99.63 \\
\hline$\%$ Assay mean \pm SD & $100.06 \pm 0.1356$ & $100.25 \pm 0.118$ & $100.49 \pm 0.356$ & $100.03 \pm 0.796$ & $99.57 \pm 0.540$ & $99.88 \pm 0.195$ \\
\hline$\%$ RSD & 0.136 & 0.116 & 0.355 & 0.796 & 0.543 & 0.195 \\
\hline
\end{tabular}

Values are given in mean $\pm S D ; n=6$

\section{Accuracy}

In the accuracy study, the \% recovery $(50,100$ and $150 \%)$ values were found to be in the range of $100.76-97.30 \%, 100.57-97.01 \%$ 99.58-98.10\% was observed for Tigecycline and both impurities studied and the \% RSD in different level was found to be less than 1 (table 8) which is the acceptable limit. Hence the method was found to be accurate. \% Recovery range is comparable to the work reported by other researchers $[8,9,11,12$ and 14].

\section{LOD and LOQ}

The least quantification and detection values (Tigecycline and its impurities 1 and 2) were originated to be $(4.15,0.143$ and 0.126$)$ and $(1.37,0.047$ and 0.071$)$. The technique is penetrating as the LOQ and LOD values were originated to be lower the specified limit. The following formula is used for the calculation of LOD and LOQ (26). LOD and LOQ values are lower in the present study compared to the other studies $[8,9]$.

$\mathrm{LOD}=3 \delta^{*} \mathrm{~S}$
$\mathrm{LOQ}=10 \delta^{*} \mathrm{~S}$

Where, $\delta=$ Standard deviation (from peak area)

$\mathrm{S}=$ slope of the linearity curve

\section{Robustness}

The parameters studied are mobile phase ratio, mobile phase $\mathrm{pH}$ and wavelength. The mobile phase ratio was observed at \pm 5 from the optimized mobile phase ratio, mobile $\mathrm{pH}$ was studied at \pm 0.1 units and wavelength was studied at \pm 5 . The reply factors experiential through the robustness study are USP resolution, relative retention time, tail factor, plate count, and \%change of peak area (table 9). The $\%$ change in the peak area values of Tigecycline and impurities 1 and 2 in the robustness study confirms that there is no considerable change was observed. This confirms that the method is found to be robust as there is no considerable change in the separation and detection of Tigecycline and impurities when a small change in the developed method conditions.

Table 7: Recovery studies

\begin{tabular}{|c|c|c|c|c|c|c|c|c|c|}
\hline \multirow{2}{*}{$\begin{array}{l}\text { Level of } \\
\text { recovery } \\
(\%)\end{array}$} & \multicolumn{2}{|c|}{$\begin{array}{l}\text { Amount recovered } \\
(\text { Practical })\left(\mu \mathrm{g} \mathrm{ml}^{-1}\right)\end{array}$} & \multicolumn{3}{|c|}{ \% Recovery } & \multirow[t]{2}{*}{$\begin{array}{l}\text { Statistical } \\
\text { evaluation }\end{array}$} & \multicolumn{3}{|c|}{ Statistical values } \\
\hline & Tig & Imp-1/2 & Tig & Imp-1 & Imp-2 & & Tig & Imp-1 & Imp-2 \\
\hline \multirow[t]{3}{*}{50} & 225 & 3 & 99.93 & 97.58 & 98.10 & mean \pm SD & $100.31 \pm$ & $97.27 \pm$ & $98.28 \pm$ \\
\hline & 225 & 3 & 100.76 & 97.20 & 98.26 & & 0.422 & 0.292 & 0.190 \\
\hline & 225 & 3 & 100.23 & 97.01 & 98.48 & $\%$ RSD & 0.420 & 0.300 & 0.193 \\
\hline \multirow[t]{3}{*}{100} & 300 & 4 & 99.85 & 99.36 & 99.58 & mean \pm SD & $99.89 \pm$ & $99.72 \pm$ & $99.31 \pm$ \\
\hline & 300 & 4 & 99.82 & 99.92 & 98.79 & & 0.108 & 0.317 & 0.449 \\
\hline & 300 & 4 & 100.01 & 99.89 & 99.55 & $\%$ RSD & 0.109 & 0.318 & 0.452 \\
\hline \multirow[t]{3}{*}{150} & 375 & 5 & 97.30 & 100.18 & 99.34 & mean \pm SD & $98.35 \pm$ & $100.33 \pm$ & $98.98 \pm$ \\
\hline & 375 & 5 & 98.73 & 100.25 & 98.78 & & 0.917 & 0.209 & 0.313 \\
\hline & 375 & 5 & 99.01 & 100.57 & 98.82 & $\%$ RSD & 0.933 & 0.209 & 0.316 \\
\hline
\end{tabular}

Values are given in mean $\pm \mathrm{SD} ; \mathrm{n}=3$ 
Table 8: Results of robustness/Ruggedness experiment

\begin{tabular}{|c|c|c|c|c|c|c|c|}
\hline $\begin{array}{l}\text { Altered } \\
\text { parameter }\end{array}$ & Actual condition & $\begin{array}{l}\text { Altered } \\
\text { condition }\end{array}$ & RT (Min) & $\begin{array}{l}\text { USP } \\
\text { resolution }\end{array}$ & $\begin{array}{l}\text { Theor } \\
\text { plates }\end{array}$ & $\begin{array}{l}\text { Peak } \\
\text { area }\end{array}$ & $\begin{array}{l}\text { \% Change in } \\
\text { peak area }\end{array}$ \\
\hline \multicolumn{8}{|l|}{ Tigecycline } \\
\hline Control Condition & NA & --- & 6.5500 & 4.99 & 4148 & 985512 & \\
\hline \multirow[t]{2}{*}{ Mobile phase ratio* } & $75: 25$ & $70: 30$ & 6.4833 & 4.97 & 4157 & 987327 & -0.184 \\
\hline & & $80: 20$ & 6.4833 & 4.91 & 4256 & 982548 & 0.301 \\
\hline \multirow{2}{*}{$\mathrm{pH}$} & 6.1 & 6.0 & 6.7667 & 4.92 & 4374 & 987955 & -0.248 \\
\hline & & 6.2 & 6.4833 & 4.27 & 4291 & 986174 & -0.067 \\
\hline Wave & 231 & 226 & 6.5167 & 5.22 & 4285 & 990364 & -0.492 \\
\hline length (nm) & & 236 & 6.4833 & 5.12 & 4266 & 987591 & -0.211 \\
\hline \multicolumn{8}{|l|}{ Imp-1 } \\
\hline Control Condition & NA & --- & 8.7333 & 6.32 & 5935 & 59731 & \\
\hline \multirow[t]{2}{*}{ Mobile phase ratio* } & $75: 25$ & $70: 30$ & 9.0000 & 6.42 & 5743 & 59337 & 0.660 \\
\hline & & $80: 20$ & 8.6833 & 6.37 & 5855 & 59889 & -0.265 \\
\hline \multirow[t]{2}{*}{$\mathrm{pH}$} & 6.1 & 6.0 & 8.9833 & 6.35 & 5769 & 59559 & 0.288 \\
\hline & & 6.2 & 8.7000 & 6.41 & 5855 & 60015 & -0.475 \\
\hline Wave & 231 & 226 & 8.7167 & 6.54 & 5892 & 60356 & -1.046 \\
\hline length (nm) & & 236 & 8.9167 & 6.47 & 5748 & 60248 & -0.866 \\
\hline \multicolumn{8}{|l|}{ Imp-2 } \\
\hline Control Condition & NA & --- & 4.8667 & & 3370 & 64034 & \\
\hline \multirow[t]{2}{*}{ Mobile phase ratio* } & $75: 25$ & $70: 30$ & 5.2000 & --- & 3437 & 63239 & 1.242 \\
\hline & & $80: 20$ & 5.0167 & --- & 3385 & 63761 & 0.426 \\
\hline \multirow[t]{2}{*}{$\mathrm{pH}$} & 6.1 & 6.0 & 5.3833 & ---- & 3352 & 63734 & 0.469 \\
\hline & & 6.2 & 5.0167 & ---- & 3427 & 63906 & 0.200 \\
\hline Wave & 231 & 226 & 5.0333 & ---- & 3371 & 63837 & 0.308 \\
\hline length (nm) & & 236 & 5.0500 & ---- & 3472 & 63730 & 0.475 \\
\hline
\end{tabular}

*Methanol: 10 mmol Triethylamine Buffer (v/v)

\section{CONCLUSION}

The present work establishes the chromatographic situations to concurrent resolve of Tigecycline and both impurities 1 and 2 is precise, robust, linear, specific, and accurate. The degradationrelated compounds do not combine Tigecycline and its impurities; thus the technique is stability-indicating. In the present technique, appraised the factors which unusually managed the resolution of the peaks. Good theoretical plates indicates the column's fruit full output. These method conditions are effective authenticated and create an effectively submission of the method for Tigecycline investigation and stability representative studies.

\section{FUNDING}

Nil

\section{AUTHORS CONTRIBUTIONS}

All authors have contributed equally.

\section{CONFLICT OF INTERESTS}

Declared none

\section{REFERENCES}

1. Kasbekar N. Tigecycline: a new glycylcycline antimicrobial agent. Am J Health Syst Pharm. 2006;63(13):1235-43. doi: 10.2146/ajhp050487, PMID 16790575.

2. Zhanel GG, Homenuik K, Nichol K, Noreddin A, Vercaigne L, Embil J, Gin A, Karlowsky JA, Hoban DJ. The glycylcyclines: a comparative review with the tetracyclines. Drugs. 2004;64(1):63-88. doi: 10.2165/00003495-200464010-00005, PMID 14723559.

3. Nguyen F, Starosta AL, Arenz S, Sohmen D, Donhofer A, Wilson DN. Tetracycline antibiotics and resistance mechanisms. Biol Chem. 2014;395(5):559-75. doi: 10.1515/hsz-2013-0292, PMID 24497223.

4. Pankey GA. Tigecycline. J Antimicrob Chemother 2005;56(3):470-80. doi: 10.1093/jac/dki248, PMID 16040625.

5. Kaewpoowat Q, Ostrosky Zeichner L. Tigecycline: a critical safety review. Expert Opin Drug Saf. 2015;14(2):335-42. doi: 10.1517/14740338.2015.997206, PMID 25539800.

6. Yamashita A, Norton E, Petersen PJ, Rasmussen BA, Singh G, Yang Y, Mansour TS, Ho DM. Muraymycins, novel peptidoglycan biosynthesis inhibitors: synthesis and SAR of their analogues. Bioorg Med Chem Lett. 2003;13(19):3345-50. doi: 10.1016/s0960-894x(03)00671-1, PMID 12951123.

7. Sharavanan SPN, Venkatesan CS, Sathiyanarayanan S, Kabilan S. Potential Impurities of tigecycline: synthesis, isolation, characterization and in vitro pharmacological evaluation. Curr Pharm Anal. 2020;16(6):730-42. doi: 10.2174/ 1573412915666190225160030.

8. Da Silva LM, Salgado HR. Validation of a stability-indicating RPLC method for the determination of tigecycline in lyophilized powder. J Chromatogr Sci. 2013;51(2):192-9. doi: 10.1093/chromsci/bms126, PMID 22832547.

9. Suneetha DA. Development and validation of stability indicating RP-HPLC method for estimation of tigecycline in bulk and its parenteral dosage forms. World J Pharm Pharm Sci. 2017;6:1096-107. doi: 10.20959/wjpps20178-9694.

10. Akiful M, Reddy S, Mulagada G, Bakshi V. Development and validation of RP-HPLC method for the estimation of tigecycline in bulk and its parenteral dosage form. International Conference Series on Multi-disciplinary Sciences. Vol. 3; 2018. p. 1-14.

11. Hua XI, Wei LI. Determination of tigecycline for injection 1with HPLC. Anhui Med Pharm J. 2009;9.

12. Mohan B, Sharma RSK, Mohan Rao SVM, gopal NVSV Estimation of related substances in tigecycline by rp-hplc Method. Orient J Chem. 2017;33(5):2608-15. doi: 10.13005/ojc/330558.

13. Silva LM, Almeida AE, Salgado HR. Thermal analysis and validation of UV and visible spectrophotometric methods for the determination of new antibiotic tigecycline in a pharmaceutical product. Adv Anal Chem. 2012;2:10-5.

14. Zorpas KM, Valsami GN, Vryonis EV, Skoutelis AT, Archontaki HA. Robust and sensitive high-performance liquid chromatographic-UV detection technique for the determination of tigecycline in rabbit plasma. J AOAC Int. 2011;94(3):847-56. doi: 10.1093/jaoac/94.3.847, PMID 21797013

15. Jasiecka Mikołajczyk A, Jaroszewski JJ. Determination of tigecycline in turkey plasma by LC-MS/MS: validation and application in a pharmacokinetic study. Pol J Vet Sci. 2017;20(2):241-9. doi: 10.1515/pjvs-2017-0029, PMID 28865218.

16. Mei S, Luo X, Li X, Li Q, Huo J, Yang L, Zhu L, Feng W, Zhou J, Shi G, Zhao Z. Development and validation of an LC-MS/MS method for the determination of tigecycline in human plasma and 
cerebrospinal fluid and its application to a pharmacokinetic study. Biomed Chromatogr. 2016;30(12):1992-2002. doi: 10.1002/bmc.3776, PMID 27245381.

17. Shao R, Li X, Hu Y, Chen J, Lou H, Dai H. Determination of tigecycline in human plasma by LC-MS/MS and its application to population pharmacokinetics study in Chinese patients with hospital-acquired pneumonia. Biomed Chromatogr. 2018;32(2):1-2. doi: 10.1002/bmc.4045, PMID 28677837.

18. Wang L, Hu X, Zhu H, Zhang X, Wang C, Han Z. Development and validation of an LC-MS/MS method for determination of tigecycline and its epimer in human plasma and its application in a pharmacokinetic study. Acta Chromatogr. 2016;28(2):23953. doi: 10.1556/1326.2016.28.4.2.

19. Panda SS, BVV RK. Development and validation of spectrophotometric and liquid chromatographic methods for estimation of tigecycline in injections. PCI- Approved-IJPSN. 2020;13(5):5148-54. doi: 10.37285/ijpsn.2020.13.5.12.

20. International conferences of harmonization validation of analytical procedures test and methodology. Vol. Q2(R1); 2005.

21. Kumar KK, Nadh RV. Reverse phase high-performance liquid chromatographic method for the determination of satranidazole in pharmaceutical formulations. Rasayan J Chem. 2011;4:681-5.

22. Sudhir MS, Venkata Nadh RV. Rasagiline hemitartrate: synthesis, characterization and RP-HPLC validation for its estimation in bulk form. Drug Invent Today. 2013;5(2):133-8. doi: 10.1016/j.dit.2013.05.002.

23. Kumar KK, Nadh RV. A validated RP-HPLC method for the estimation of melphalan in tablet dosage forms. Rasayan J Chem. 2011;4:863-7.

24. Prasad GG, Nadh RV. Determination of mianserin using tropaeoline-000 by ion-pair formation. Int J Appl Pharm. 2019;11:168-73.

25. Prasad GG, Nadh RV, Kiran KK. Piperacillin estimation by ionassociative complex formation. Asian J Pharm Clin Res. 2019;12:1-5.

26. KS, KI. Development, evaluation and RP-HPLC method for simultaneous estimation of quercetin, ellagic acid and kaempferol in a polyherbal formulation. Int J Appl Pharm. 2021;13:183-92. doi: 10.22159/ijap.2021v13i3.41028, doi: 10.22159/ijap.2021v13i3.41028. 